Article

\title{
A Comprehensive Exploration on Pollution Characteristics and Ecological Risks of Heavy Metals in Surface Paddy Soils around a Large Copper Smelter, Southeast China
}

\author{
Xiyang Wang ${ }^{1}$, Liang $\mathrm{Li}^{1}$, Naijia Guo ${ }^{2}$, Zaijun Xin ${ }^{1}$, Xiaohui $\mathrm{Li}^{1}$, Xiaoyan Sun ${ }^{1}$ and $\mathrm{Ya} \mathrm{Li}^{1}{ }^{1}$ * \\ 1 Jiangxi Engineering and Technology Research Center of Eco-Remediation of Heavy Metal Pollution, \\ Institute of Microbiology, Jiangxi Academy of Sciences, Nanchang 330096, China; \\ wangxiyang@jxas.ac.cn (X.W.); liliang@jxas.ac.cn (L.L.); xinzaijun@jxas.ac.cn (Z.X.); \\ Lixiaohui@jxas.ac.cn (X.L.); sunxiaoyan@jxas.ac.cn (X.S.) \\ 2 Agricultural Ecology and Resource Protection Agency of Jiangxi Province, Nanchang 330046, China; \\ njguo@issas.ac.cn \\ * Correspondence: liya@jxas.ac.cn; Tel.: +86-25-8817-7105
}

\section{check for}

updates

Citation: Wang, X.; Li, L.; Guo, N.; Xin, Z.; Li, X.; Sun, X.; Li, Y. A Comprehensive Exploration on Pollution Characteristics and Ecological Risks of Heavy Metals in Surface Paddy Soils around a Large Copper Smelter, Southeast China. Sustainability 2021, 13, 13359. https:/ / doi.org/10.3390/su132313359

Academic Editor: Zygmunt Mariusz Gusiatin

Received: 28 October 2021

Accepted: 29 November 2021

Published: 2 December 2021

Publisher's Note: MDPI stays neutral with regard to jurisdictional claims in published maps and institutional affiliations.

Copyright: (c) 2021 by the authors. Licensee MDPI, Basel, Switzerland. This article is an open access article distributed under the terms and conditions of the Creative Commons Attribution (CC BY) license (https:/ / creativecommons.org/licenses/by/ $4.0 /)$.
Abstract: To assess heavy metal pollution and ecological risk, a total of 28 surface paddy soil samples were collected and analyzed around a famous copper smelter in Guixi, China. The results showed that all sites were heavily contaminated by both $\mathrm{Cu}$ and $\mathrm{Cd}$, compared with soil background values, whose average concentrations exceeded the standard by 5.7 and 12.3 times, respectively, posing a slight ecological risk related to $\mathrm{Cu}$ (potential ecological risk index $<40$ ) and an extremely serious ecological risk related to $\mathrm{Cd}$ (potential ecological risk index $>320$ ). The risks were also demonstrated through the speciation analyses of $\mathrm{Cu}\left(\mathrm{CaCl}_{2}-\mathrm{Cu} 2.63 \%\right.$, acid-soluble $\mathrm{Cu} 8.67 \%$, and residual $\mathrm{Cu}$ $74.17 \%$, on average) and $\mathrm{Cd}\left(\mathrm{CaCl}_{2}-\mathrm{Cd} 47.30 \%\right.$, acid-soluble $\mathrm{Cd} 45.02 \%$, and residual $\mathrm{Cd} 28.87 \%$, on average) in the surface paddy soil, including the use of a $\mathrm{CaCl}_{2}$ extraction procedure and the BCR (Community Bureau of Reference) sequential extraction scheme. Several soil properties (residual carbon, cation exchange capacity, and soil texture) were significantly correlated with soil Cd but made a small contribution to their variability with a poor linear fit because of external Cd input to the soil, while soil total potassium largely influenced the soil $\mathrm{Cu}$ species except for residual $\mathrm{Cu}$. Therefore, an effective $\mathrm{Cu}$ pollution regulation strategy through soil potassium control is suggested for this smelter soil.

Keywords: smelting; paddy soil; heavy metals; speciation analysis; soil properties

\section{Introduction}

With rapid urbanization and industrial development, the heavy metal pollution of agricultural soil has been a great challenge all over the world [1-3]. A report from the Ministry of Environmental Protection of China (MEP) shows that $19.40 \%$ of the investigated cropland soil samples had pollutants exceeding the standard, and most of them were heavy metals [4]. Anthropogenic inputs, such as industrial emissions from nonferrous mining and smelting activities have been regarded as the most important sources of heavy metal pollution in China's agricultural soils in the past few decades [3,4].

Guixi Smelter is the largest modern copper smelter in China [5]. The long history of smelting has resulted in significantly increased concentrations of copper $(\mathrm{Cu})$, cadmium $(\mathrm{Cd})$, lead $(\mathrm{Pb})$, and zinc $(\mathrm{Zn})$ in the surrounding soils and nearby crops [6]. In the past 15 years, many reports have documented that the cropland soils around the smelter were seriously contaminated with $\mathrm{Cu}$ and $\mathrm{Cd}$, posing high ecological risk related to these heavy metals, and some soils may also be polluted with $\mathrm{Pb}$ and $\mathrm{Zn}$ [7-9]. Subsequently, some pollution control and remediation measures have been put in place for the cropland soils near Guixi Smelter [8], e.g., (a) decreasing emissions of heavy metal elements through improving smelting processes [6], (b) optimizing fertilization [8,9], and (c) the in situ 
passivation of soil heavy metals by application of alkaline materials [9]. These measures are mainly to reduce the external input of heavy metals and to change their mobility in soil to achieve the safe utilization of farmland soil [10].

Currently, using various extraction schemes (e.g., $\mathrm{CaCl}_{2}$ extraction procedure, $\mathrm{BCR}$ sequential extraction scheme, and Tessier sequential extraction scheme) to evaluate the mobility and availability of heavy metals in soils is a major improvement over only evaluating the level of heavy metal content [11-13]. In addition, when evaluating the risk of heavy metal pollution in soil of agricultural land, the influence of soil properties on its availability is often ignored [14,15], in general, the availability of heavy metals in soil have been demonstrated to be associated with soil properties, including the $\mathrm{pH}$ [15], soil organic carbon content (SOC) [16], cation exchange capacity (CEC) [17], soil mechanical composition [18], and soil nutrients (e.g., nitrogen, phosphorus and potassium) [19]. However, no correlations between the soil properties and heavy metal contents were observed in agricultural soil in the northeast part of Tadla plain (Morocco) due to the influence of anthropogenic sources [14].

Thus, with a comprehensive investigation and analysis of paddy soils around the smelter, the objectives of this study were to (1) characterize the contamination status and ecological risk level after some pollution control; (2) reveal the characteristics of heavy metal species in the smelter-impacted paddy soil; and (3) explore the relationship between heavy metal species and soil properties in the study area, suggesting some sustainable and effective measures for the current safe soil use or soil remediation in China.

\section{Materials and Methods}

\subsection{Study Area}

Guixi Smelter, the largest porphyry copper mine smelter in China, lies to the north of the Xinjiang River in Guixi city, Southeast China, and all sampling sites were located on both sides of the Xinjiang River around the smelter (Figure 1). This area has a subtropical monsoon humid climate, and the soil parent material is derived from cretaceous red sandstone. The mean annual temperature is $18.2{ }^{\circ} \mathrm{C}$, average annual precipitation is $1836.2 \mathrm{~mm}$, and the average annual wind speed is $2.1 \mathrm{~m} \cdot \mathrm{s}^{-1}$. For decades, almost 260 ha of paddy fields around the smelter have been contaminated by heavy metals through atmospheric deposition and wastewater discharge from smelting activities $[6,7,10]$.

\subsection{Soil Sampling and Analysis}

According to the distribution of rice fields around the smelter, a total of 28 surface soil samples were collected (to a depth of $20 \mathrm{~cm}$ ) in July 2018 after the early-rice harvest; the nearest sampling site to the smelter was $0.89 \mathrm{~km}$, and the farthest sampling site from the smelter was $9.6 \mathrm{~km}$ (Figure 1). Each sample was a mixture of samples taken from five different directions in the same rice field, all samples were air dried and crushed, after which visible roots were removed, and then the soil samples were passed through a 2-mm sieve and stored for subsequent analyses [20].

Concentrations of soil heavy metals $(\mathrm{Cu}, \mathrm{Cd}, \mathrm{Pb}, \mathrm{Zn}, \mathrm{Cr}$, and $\mathrm{Ni})$ were determined using an inductively coupled plasma mass spectrometry method (ICP-MS, X2, Thermo Fisher, USA) with $\mathrm{HNO}_{3}-\mathrm{HF}-\mathrm{HClO}_{3}$ digestion as pretreatment [21]. Determination of soil physicochemical properties followed the methods recommended by Lu (2000) [22]. The total SOC of each sample was determined using oxidation method of potassium dichromate combined with concentrated sulfuric acid, soil $\mathrm{pH}$ was determined electrometrically using a pH electrode, soil total nitrogen (TN) was determined using Kjeldahl method with an automatic Kjeldahl azotometer (K9860, Hanon, Shandong province, China), soil available nitrogen (AN) was determined using alkali-hydrolyzed diffusion method, soil total phosphorus (TP) was determined using $\mathrm{H}_{2} \mathrm{SO}_{4}-\mathrm{HClO}_{4}$ digestion-phosphomolybdate blue spectrophotometry (UV/VIS-4802, UNICO, Shanghai, China), soil available phosphorus (AP) was measured using $\mathrm{NH}_{4} \mathrm{~F}-\mathrm{HCl}$ extraction-phosphomolybdate blue spectrophotometry (UV/VIS-4802, UNICO, Shanghai, China), soil total potassium (TK) was measured 
using $\mathrm{NaOH}$-melting-flame photometric method (FP6431, Shanghai, China), soil available potassium (AK) was determined using $\mathrm{NH}_{4} \mathrm{OAc}$-extraciton-flame photometric method (FP6431, Shanghai, China), Cation exchange capacity (CEC) was measured using $1 \mathrm{M}$ $\mathrm{NH}_{4} \mathrm{OAc}$ exchange method, and soil particle size distribution was measured using the pipette method. Soil humus fractions, including humic acid, fulvic acid, and residual organic carbon, were determined by a modified Linfa Hill method [23]. To measure the mobility and bioavailability of heavy metals in soil, the heavy metal concentrations in soil exchangeable fraction were extracted using $0.01 \mathrm{M} \mathrm{CaCl}_{2}$ and were analyzed by ICP-MS [24]; the chemical fractions of soil heavy metals were analyzed by BCR threestep sequential extraction (F1 acid-soluble, F2 reducible, F3 oxidizable, and F4 residual fraction) [13].

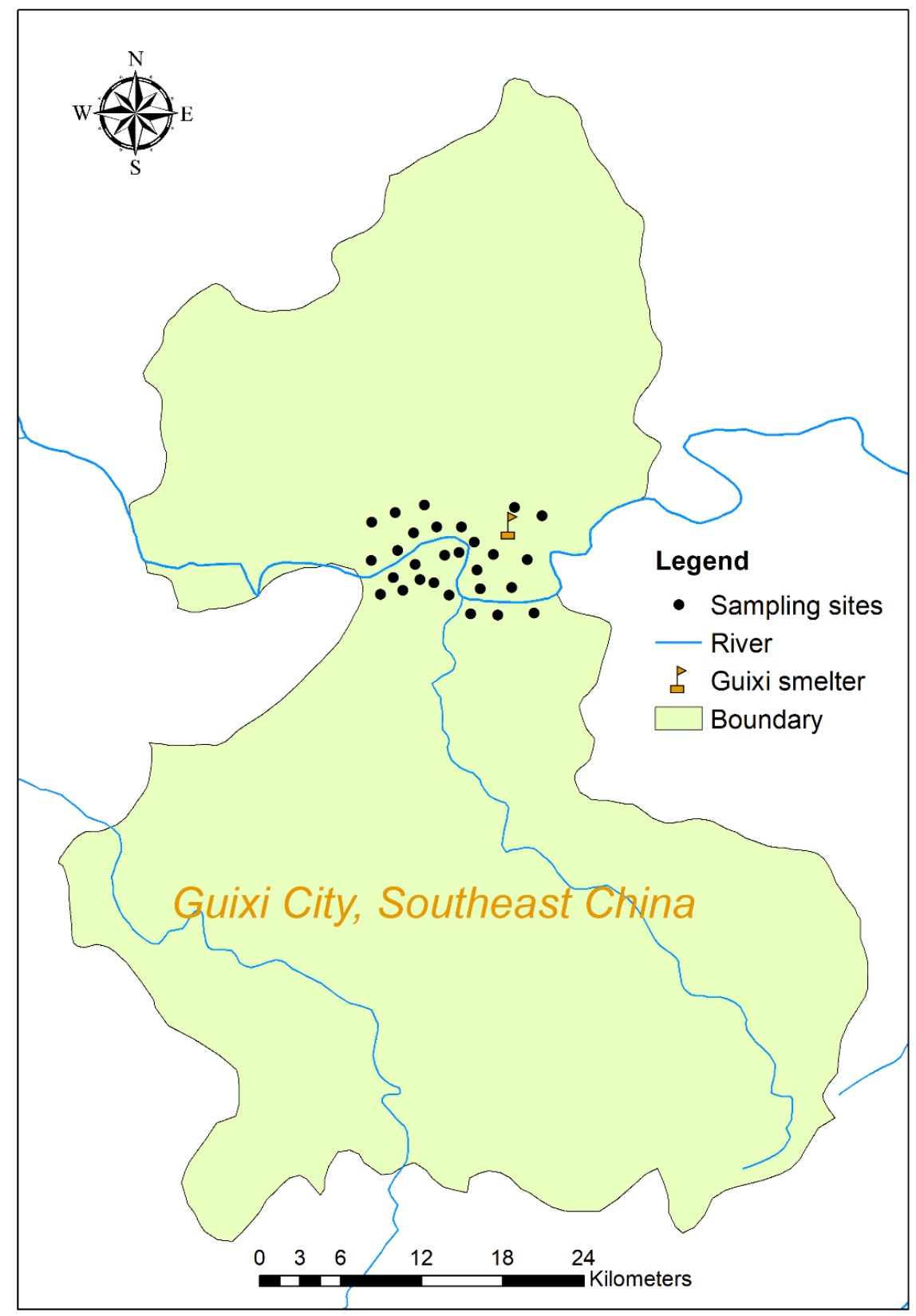

Figure 1. Spatial distribution of sampling sites. 


\subsection{Soil Heavy Metal Pollution Assessment}

The geoaccumulation index method is mainly used to evaluate the pollution level of heavy metals. The calculation formula is as follows [25]:

$$
I_{\text {geo }}=\log _{2}\left(\frac{C_{i}}{1.5 \times B_{i}}\right)
$$

where $I_{\text {geo }}$ is the geoaccumulation index of heavy metal $i ; C_{i}$ represents the measured value of heavy metal $i ; B_{i}$ represents the soil background value of heavy metal $i$ in Guixi city; and 1.5 is the correction coefficient. The classification standard is shown in Supplementary Material, Table S1 [26].

The potential ecological risk index method is used to evaluate the potential ecological risk of soil heavy metal pollution. The calculation formula is as follows [27]:

$$
E_{i}=T_{i} \times \frac{C_{i}}{B_{i}}
$$

where $E_{i}$ is the individual potential ecological risk index of heavy metal $i ; C_{i}$ represents the measured value of heavy metal $i ; B_{i}$ represents the soil background value of heavy metal $i$ in Guixi city; $T_{i}$ is the toxic response factor of heavy metal $i\left(T_{C u}=5, T_{C d}=30, T_{P b}=5\right.$, $T_{Z n}=1, T_{C r}=2, T_{N i}=5$ ) [27]; and $R I$ is the comprehensive potential ecological risk index. The classification standard is shown in Table S2 [28].

\subsection{Statistical Analysis}

Pearson's tests were used to determine whether the soil $\mathrm{pH}$, soil humus fraction, $\mathrm{SOC}$ and soil texture were significantly correlated with the soil heavy metals and their chemical fractions. All these above statistical analyses were performed using Statistical Package for Social Sciences (SPSS) software [29,30]. A linear regression was used to determine the relative effect of each correlated predictor variable from Pearson's tests based on the coefficient of determination $\left(R^{2}\right)$, which was performed in Origin 8.5 (Origin Lab Corporation, Northampton, MA, USA).

\section{Results}

\subsection{Characteristics of Heavy Metal Pollution}

The soil $\mathrm{pH}$ values of all sites were less than 7.0 , with a mean value of 5.2 , and $85.7 \%$ of the sites had $\mathrm{pH}$ values less than 5.5 with a CV of 0.08 (Table S3). The average total $\mathrm{Cu}$ and $\mathrm{Cd}$ contents were higher than the risk-screening values for soil contamination of agricultural land (Cu $50 \mathrm{mg} \cdot \mathrm{kg}^{-1}$ and Cd $0.3 \sim 0.4 \mathrm{mg} \cdot \mathrm{kg}^{-1}$ in GB 15618-2018) issued by the State Environmental Protection Administration of China, and the average concentrations of $\mathrm{Cu}, \mathrm{Cd}, \mathrm{Pb}$, and $\mathrm{Zn}$ in the soil exceeded the soil background value [31] by 5.7, 12.3, 2.1, and 1.6 times, respectively (Table 1). Obviously, the excess $\mathrm{Cu}$ and $\mathrm{Cd}$ in the paddy soil around the copper smelter was more serious than that of the other heavy metals.

\begin{tabular}{|c|c|c|c|c|c|}
\hline Heavy Metal & $\begin{array}{l}\text { Maximum Value } \\
\quad\left(\mathrm{mg} \cdot \mathrm{kg}^{-1}\right)\end{array}$ & $\underset{\left(\mathrm{mg} \cdot \mathrm{kg}^{-1}\right)}{\operatorname{Minimum} \text { Value }}$ & $\begin{array}{c}\text { Mean } \\
\left(\mathrm{mg} \cdot \mathrm{kg}^{-1}\right)\end{array}$ & $\mathrm{CV}$ & $\begin{array}{l}\text { Background Value } \\
\left(\mathrm{mg} \cdot \mathrm{kg}^{-1}\right)\end{array}$ \\
\hline $\mathrm{Cu}$ & 586.21 & 38.14 & 118.78 & 1.04 & 20.80 \\
\hline $\mathrm{Cd}$ & 3.79 & 0.48 & 1.23 & 0.69 & 0.10 \\
\hline $\mathrm{Cr}$ & 80.28 & 12.79 & 42.46 & 0.34 & 48.00 \\
\hline $\mathrm{Pb}$ & 127.00 & 39.79 & 67.86 & 0.38 & 32.10 \\
\hline $\mathrm{Zn}$ & 465.03 & 43.30 & 110.72 & 0.75 & 69.10 \\
\hline $\mathrm{Ni}$ & 31.09 & 3.99 & 16.66 & 0.43 & 19.00 \\
\hline
\end{tabular}

Table 1. Statistical characteristics of the heavy metal content in smelter-impacted paddy soil.

$\overline{\mathrm{CV}}$, coefficient of variation; the soil background values were referenced to Xu et al. (2015) [31]. 
The $I_{g e o}$ data also showed a higher pollution level of $\mathrm{Cu}$ and $\mathrm{Cd}$ in the paddy soil in the study area compared with the other heavy metals; the proportion of polluted points reached $100 \%$, and more than $78.0 \%$ of the sites were moderately polluted by Cd (Figure 2). In addition, parts of the sites were slightly contaminated by $\mathrm{Pb}$ and $\mathrm{Zn}$. Serious $\mathrm{Cd}$ pollution in the soil in the study area also resulted in a high potential ecological risk; $100 \%$ of the sites posed a heavy risk, and $39.3 \%$ of the sites reached extremely serious risk levels. Only $17.9 \%$ of the sites had a heavy potential ecological risk related to $\mathrm{Cu}$ pollution (Figure 3). Other heavy metals posed a very slight potential ecological risk with a $<40$ potential ecological risk index (Figure 3).

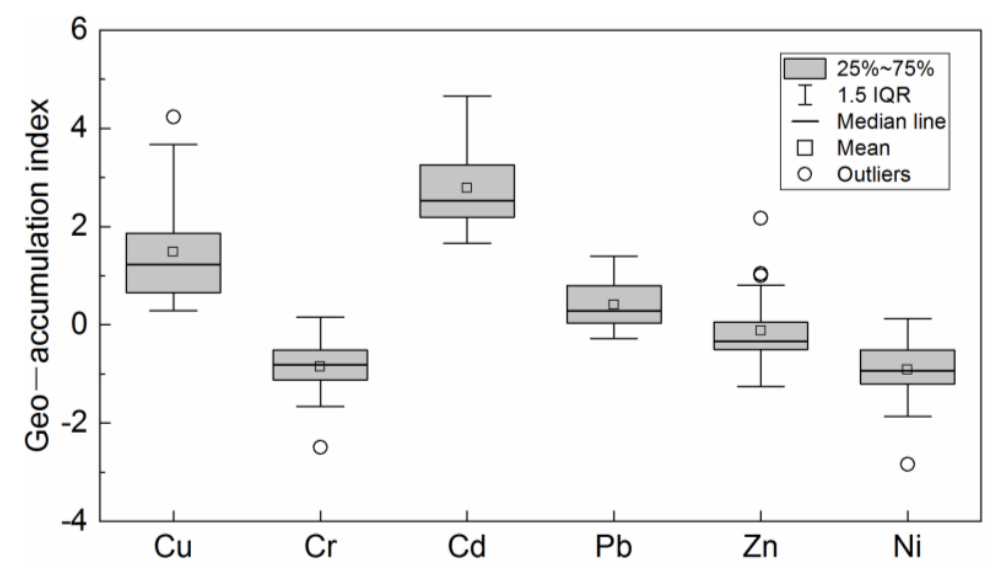

Figure 2. Igeo of heavy metals in smelter-impacted paddy soil. Igeo, geoaccumulation index; $1.5 \mathrm{IQR}$, 1.5 times interquartile range.

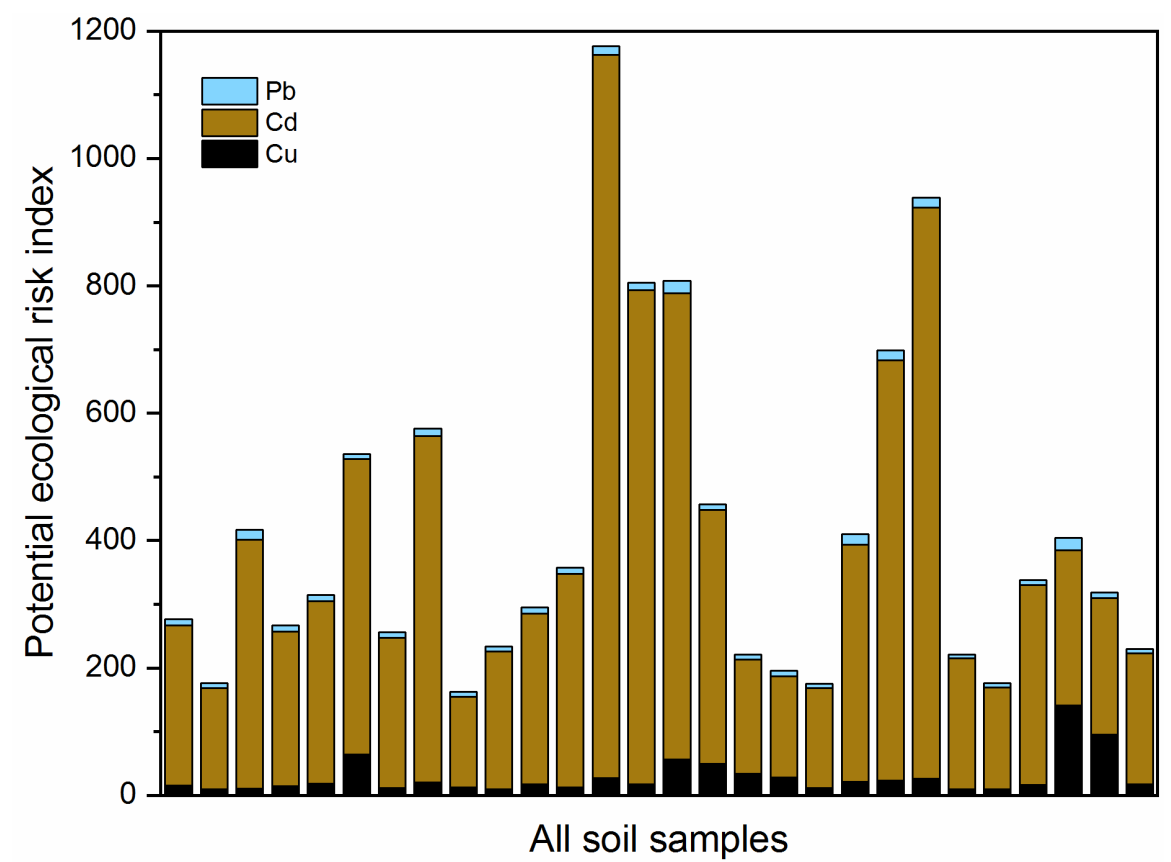

Figure 3. Potential ecological risk indices of heavy metals in smelter-impacted soil.

\subsection{Speciation Analysis of $\mathrm{Cu}$ and $\mathrm{Cd}$ in Soil}

$\mathrm{Cu}$ and $\mathrm{Cd}$ were the main heavy metal pollutants in the surface paddy soil around the smelter; however, they differed in bioavailability due to the different distributions of $\mathrm{CaCl}_{2}$ extractable $\mathrm{Cu}\left(\mathrm{CaCl}_{2}-\mathrm{Cu}\right)$ and $\mathrm{Cd}\left(\mathrm{CaCl}_{2}-\mathrm{Cd}\right)$ in the soil (Figure $\left.4 \mathrm{~A}, \mathrm{~B}\right)$. The percentage of $\mathrm{CaCl}_{2}-\mathrm{Cu}$ relative to the total $\mathrm{Cu}$ in the soil $\left(\mathrm{CaCl}_{2}-\mathrm{Cu} /\right.$ total $\left.\mathrm{Cu}\right)$ was $0.32 \sim 17.90 \%$, with a mean value of $2.63 \%$, and $89.3 \%$ of the sites had $<5 \% \mathrm{CaCl}_{2}-\mathrm{Cu} /$ total $\mathrm{Cu}$ in soil (Figure $4 \mathrm{~A}$ ), 
while the percentage of $\mathrm{CaCl}_{2}-\mathrm{Cd}$ relative to total $\mathrm{Cd}\left(\mathrm{CaCl}_{2}-\mathrm{Cd} /\right.$ total $\left.\mathrm{Cd}\right)$ was $4.31 \sim 87.54 \%$, with a mean value of $47.3 \%$, and $71.4 \%$ of the sites had $>40 \% \mathrm{CaCl}_{2}-\mathrm{Cd} /$ total $\mathrm{Cd}$ in the soil (Figure 4B).

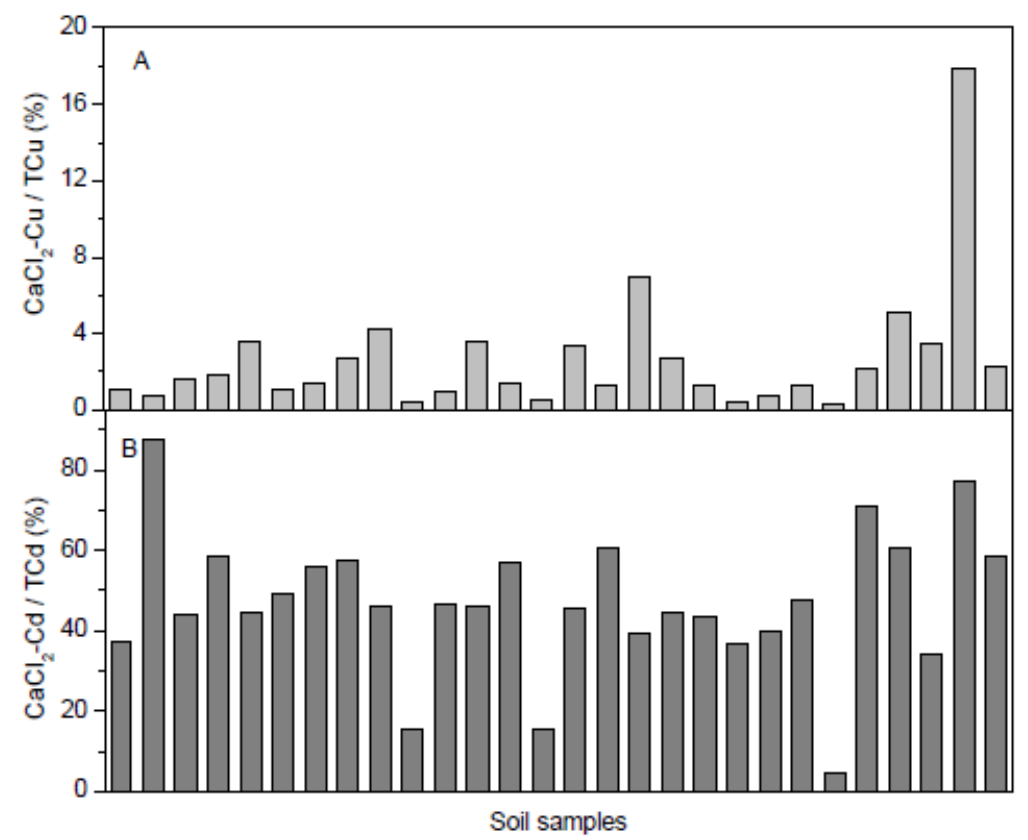

Figure 4. The percentage of $\mathrm{CaCl}_{2}-\mathrm{Cu}$ relative to the TCu in the soil (A) and the percentage of $\mathrm{CaCl}_{2}$ $\mathrm{Cd}$ relative to the TCd in the soil (B). $\mathrm{CaCl}_{2}-\mathrm{Cu}, \mathrm{CaCl}_{2}$ extractable $\mathrm{Cu} ; \mathrm{CaCl}_{2}-\mathrm{Cd}, \mathrm{CaCl}_{2}$-extractable $\mathrm{Cd}$; $\mathrm{TCd}$, total $\mathrm{Cd} ; \mathrm{TCu}$, total $\mathrm{Cu}$.

Similar speciation characteristics of $\mathrm{Cu}$ and $\mathrm{Cd}$ in the soil were also observed through the BCR-based fractionation of $\mathrm{Cu}$ and $\mathrm{Cd}$ (Figure $5 \mathrm{a}, \mathrm{b}$ ). The percentages of the acidsoluble (F1), reducible (F2), oxidizable (F3), and residual fractions (F4) of Cd relative to the total Cd were $11.38 \sim 82.93 \%$ (an average of $45.02 \%$ ), $2.54 \sim 53.55 \%$ (an average of $23.53 \%$ ), $0.04 \sim 8.77 \%$ (an average of $2.57 \%$ ), and $5.50 \sim 72.01 \%$ (an average of $28.87 \%$ ), respectively (Figure 5a), while the proportions of $\mathrm{F} 1-\mathrm{Cu}, \mathrm{F} 2-\mathrm{Cu}, \mathrm{F} 3-\mathrm{Cu}$, and $\mathrm{F} 4-\mathrm{Cu}$ relative to the total $\mathrm{Cu}$ were $0.66 \sim 39.86 \%$ (an average of $8.67 \%$ ), $1.62 \sim 11.10 \%$ (an average of $4.27 \%$ ), 3.43 39.47\% (an average of $12.88 \%$ ), and $18.96 \sim 93.34 \%$ (an average of $74.17 \%$ ), respectively (Figure $5 b)$. Therefore, the BCR-based Cd speciation analysis indicated that the surface smelterimpacted paddy soil had a high mobility and availability of $\mathrm{Cd}$ because of the largest fraction of F1-Cd; accordingly, the surface smelter-impacted paddy soil had a relatively low $\mathrm{Cu}$ ecological risk due to the dominant F4-Cu fraction in the $\mathrm{Cu}$ species (Figure 5a,b).

\subsection{Relationships of $\mathrm{Cu}$ and $\mathrm{Cd}$ Species with Soil Properties}

Pearson's correlation analyses (Table S4) revealed that $\mathrm{CaCl}_{2}-\mathrm{Cu}$ was significantly correlated with TCu, F1-Cu, and F3-Cu, and the corresponding adjusted coefficients of determination $\left(R^{2}\right)$ of the linear equation between them were $0.42,0.40$, and 0.40 , respectively (Figure $\mathrm{S} 1$ ). $\mathrm{CaCl}_{2}-\mathrm{Cd}$ was significantly correlated with TCd, F1-Cd, F2-Cd, and F3-Cd (Table S4), and the corresponding $R^{2}$ values of the linear fitting equation were $0.73,0.53$, 0.42 , and 0.15 (Figure S2). The $R^{2}$ increased to 0.67 through the establishment of a stepwise regression equation based on the three BCR-based Cd fractions (F1-Cd and F2-Cd, entered; F3-Cd, excluded), suggesting a strong linear relationship between the $\mathrm{CaCl}_{2}$ extractable $\mathrm{Cd}$ and the BCR-based Cd fraction in the soil in the study area. No obvious correlation between $\mathrm{Cu}$ and $\mathrm{Cd}$ in the soil in the study area was observed, regardless of the $\mathrm{Cu}$ and $\mathrm{Cd}$ species (Table S4). 


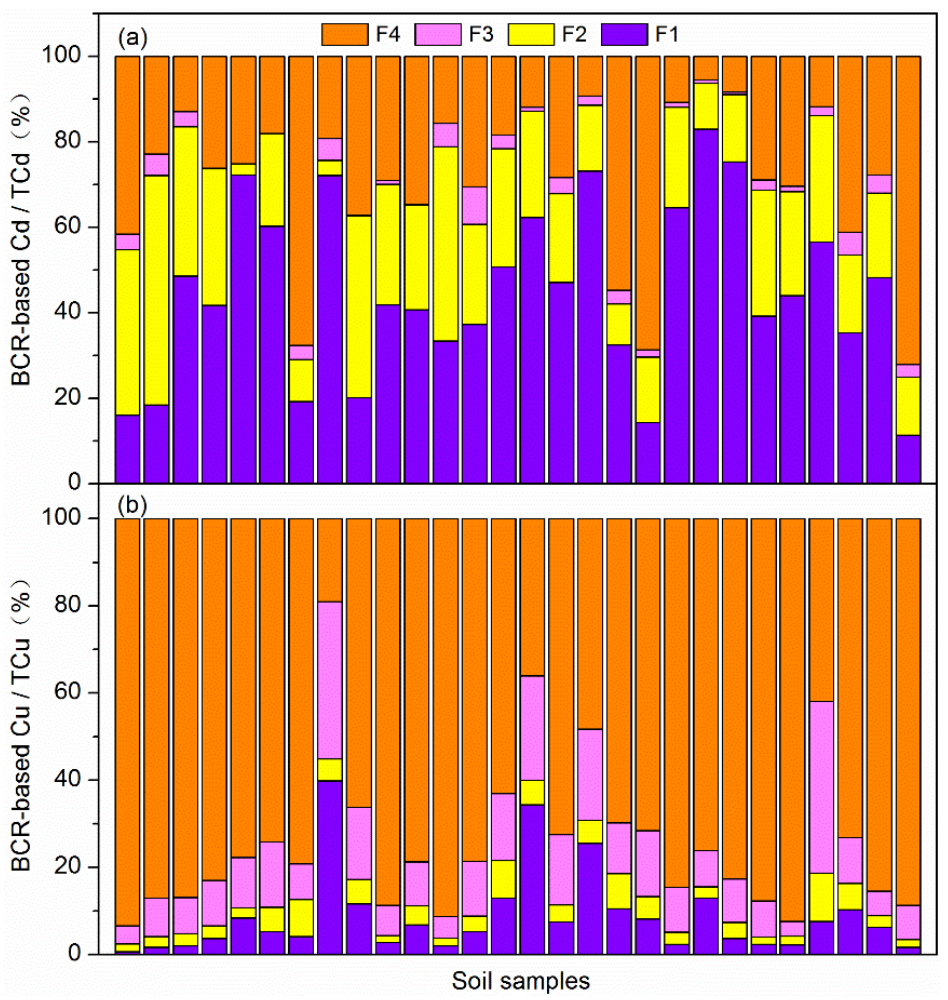

Figure 5. The percentage of BCR-based fractionation of $\mathrm{Cd}$ relative to the $\mathrm{TCd}$ in the soil (a) and the percentage of BCR-based fractionation of $\mathrm{Cu}$ relative to the TCu in the soil (b). F1, acid-soluble; F2, reducible; F3, oxidizable; F4, residual fraction; $\mathrm{TCd}$, total $\mathrm{Cd}$; $\mathrm{TCu}$, total $\mathrm{Cu}$.

Among the soil chemical properties, the soil $\mathrm{pH}$ was poorly correlated with all $\mathrm{Cu}$ and $\mathrm{Cd}$ species, while the residual organic carbon (Res-C) in SOC was significantly positively correlated with F2-Cd, and the soil CEC was significantly correlated with F2-Cd, F3-Cd, and F4-Cd (Table S5), but the goodness of fit of the linear equations between them was poor (Table 2). The soil TK was significantly negatively correlated with $\mathrm{TCu}, \mathrm{CaCl}_{2}-\mathrm{Cu}, \mathrm{F} 1-\mathrm{Cu}$, $\mathrm{F} 2-\mathrm{Cu}$, and F3-Cu (Table S5), and the corresponding $R^{2}$ values of the linear equation between TK and each $\mathrm{Cu}$ species were $0.57,0.33,0.48,0.29$, and 0.63 (Table 2), suggesting that TK had a strong influence on soil $\mathrm{Cu}$ variability, especially on oxidizable $\mathrm{Cu}$ (F3-Cu) (Table 2).

Table 2. Relationship between $\mathrm{Cu}$ and $\mathrm{Cd}$ species with soil chemical properties.

\begin{tabular}{|c|c|c|c|c|}
\hline Dependent Variable & Independent Variable & Linear Regression Model & Adjusted $R^{2}$ & $p$ Value (F-Test) \\
\hline \multirow{3}{*}{ TCd } & SOC & $T C d=0.11 \times S O C-0.04$ & 0.14 & 0.029 * \\
\hline & $\operatorname{ResC}$ & $T C d=0.12 \times \operatorname{Res} C+0.32$ & 0.16 & 0.019 * \\
\hline & SOC & $F 2 C d=0.01 \times S O C-0.03$ & 0.13 & 0.034 * \\
\hline \multirow[t]{2}{*}{$\mathrm{F} 2 \mathrm{Cd}$} & ResC & $F 2 C d=0.01 \times \operatorname{Res} C-0.00$ & 0.17 & $0.018 *$ \\
\hline & CEC & $F 2 C d=0.02 \times C E C-0.03$ & 0.29 & $0.002 * *$ \\
\hline $\mathrm{F} 3 \mathrm{Cd}$ & CEC & $F 3 C d=0.001 \times C E C+0.00$ & 0.14 & $0.028 *$ \\
\hline $\mathrm{F} 4 \mathrm{Cd}$ & CEC & $F 4 C d=0.01 \times C E C+0.01$ & 0.29 & $0.002 * *$ \\
\hline $\mathrm{TCu}$ & TK & $T C u=-14.62 \times T K+427.10$ & 0.57 & $0.000^{* *}$ \\
\hline $\mathrm{CaCl}_{2} \mathrm{Cu}$ & TK & $\mathrm{CaCl}_{2} \mathrm{Cu}=-1.26 \times \mathrm{TK}+31.66$ & 0.33 & $0.001^{* *}$ \\
\hline $\mathrm{F} 1 \mathrm{Cu}$ & TK & $F 1 C u=-1.41 \times T K+36.43$ & 0.48 & $0.000 * *$ \\
\hline $\mathrm{F} 2 \mathrm{Cu}$ & TK & $F 2 C u=-0.77 \times T K+20.17$ & 0.29 & $0.002 * *$ \\
\hline $\mathrm{F} 3 \mathrm{Cu}$ & TK & $F 3 C u=-1.53 \times T K+41.54$ & 0.63 & $0.000 * *$ \\
\hline
\end{tabular}

SOC, soil organic carbon; ResC, residual organic carbon; CEC, cation exchange capacity; TK, total potassium; TCd, total Cd; F2Cd, reducible $\mathrm{Cd}$; $\mathrm{F} 3 \mathrm{Cd}$, oxidizable $\mathrm{Cd}$; $\mathrm{F} 4 \mathrm{Cd}$, residual $\mathrm{Cd}$; $\mathrm{TCu}$, total $\mathrm{Cu}$; $\mathrm{CaCl} 2 \mathrm{Cu}, \mathrm{CaCl} 2$ extractable $\mathrm{Cu}$; $\mathrm{F} 1 \mathrm{Cu}$, acid-soluble $\mathrm{Cu}$; $\mathrm{F} 2 \mathrm{Cu}$, reducible $\mathrm{Cu}$; $\mathrm{F} 3 \mathrm{Cu}$, oxidizable $\mathrm{Cu}$. ${ }^{*}$ Significant at $p<0.05 ;{ }^{* *}$ significant at $p<0.01$. 
A significant linear correlation between the soil mechanical composition and different Cd species was observed through Pearson correlation analysis in which the sand content was significantly negatively correlated with TCd, F2-Cd, and F3-Cd, while both the silt and clay contents were significantly positively correlated with TCd, F2-Cd, and F3-Cd (Table S5). The linear fitting results showed that the soil mechanical composition had a low impact on soil Cd variability because of the low goodness of fit in the linear equations $\left(R^{2}<30 \%\right.$ ) (Figure S3). In addition, all soil Cu species were poorly correlated with the sand, silt and clay contents (Table S5).

\section{Discussion}

\subsection{Pollution Characteristics and Risk Assessment}

The heavy metal geoaccumulation index indicated that the pollution level was ranked as $\mathrm{Cd}>\mathrm{Cu}>\mathrm{Pb}>\mathrm{Zn}$, the heavy pollutant was $\mathrm{Cd}$, and the moderate pollutant was $\mathrm{Cu}$ (Figure 2). All sites had serious ecological risk related to $\mathrm{Cd}$ in the surface smelter-impacted paddy soil (Figure 3). These results are basically consistent with the serious combined pollution of $\mathrm{Cu}$ and $\mathrm{Cd}$ that existed in the soil around this smelter [10]; by contrast, there was a large decline $(43.4 \%)$ in the TCu concentration in the surface paddy soil in the study area compared to 14 years ago [7] due to the improvement in copper smelting technology and the intensification of heavy metal pollution control $[8,10]$.

Chemical speciation analysis of the soil heavy metals indicated that the surface paddy soil in the study area had high $\mathrm{Cd}$ bioavailability, while stable residual $\mathrm{Cu}$ (F4-Cu) dominated the $\mathrm{Cu}$ in the soil (Figures 3 and 4). In a previous study [7], the surface paddy soil in the study area had $>80 \% \mathrm{MgCl}_{2}$ extractable $\mathrm{Cd}$, which is much higher than that in this study $\left(\mathrm{CaCl}_{2}-\mathrm{Cd}\right.$, an average of $\left.47.27 \%\right)$, and the dominant $\mathrm{Cu}$ species were $\mathrm{NaOAc-HOAc-}$ extracted $\mathrm{Cu}$ and acidic $\mathrm{H}_{2} \mathrm{O}_{2}$-extracted $\mathrm{Cu}$ with a higher bioavailability than that in this study. The reduction in $\mathrm{Cu}$ and $\mathrm{Cd}$ pollution risk may be due to the increase in pollution regulation and the improvement of the copper smelting process in Guixi Smelter over the last decade [8].

\subsection{Effects of Soil Properties on Heavy Metal Species}

In this study, soil TCu and BCR-based $\mathrm{Cu}$ species were poorly correlated with the soil TCd and BCR-based Cd fractions (Table S4), which probably resulted from the complexity of the heavy metal pollution sources, such as wastewater irrigation, atmospheric deposition, or both factors $[6,10]$. Generally, a negative correlation between soil $\mathrm{pH}$ and heavy metal mobility and bioavailability has been well documented in numerous studies [15]; however, the soil $\mathrm{pH}$ was very poorly correlated with the $\mathrm{Cu}$ species and $\mathrm{Cd}$ species in this work (Table S5), which can be ascribed to a small $\mathrm{pH}$ variation in the soil samples with a $\mathrm{CV}<0.1$ (Table S3). The BCR-based soil Cd species were significantly correlated with several soil properties, including res-C, CEC, clay, silt, and sand (Table S5), but these soil properties did not fit the variability of the corresponding soil $\mathrm{Cd}$ species well, with a low coefficient of determination of the linear fitting equation (Table 2), which may be attributed to the large effect of external Cd input (e.g., atmospheric deposition) on the bioavailability of soil $\mathrm{Cd}$ that offsets the impacts of those internal properties in soil, since the newly deposited $\mathrm{Cd}$ was presented as higher bioavailable fractions compared to those in original soils near Guixi Smelter [6]. Among these soil properties, soil TK was demonstrated to be closely associated with different species of $\mathrm{Cu}$ except $\mathrm{F} 4-\mathrm{Cu}$ and had a high goodness of fit with F3-Cu and F1-Cu (Table 2).

Of course, the phytoavailability and ecological risk of heavy metals are also related to soil types, cropping systems, and soil amendments. Giannakis et al. (2021) concluded a low environmental risk of sludge-based biosolids when utilized in the corn field, but this varied with soil type [32]. Huang et al. (2018) developed an integrated pollution evaluation method for assessing the ecological and health risks of heavy metal pollution under different anthropogenic emissions and cropping systems in peri-urban areas [33]. Although this study comprehensively investigated and evaluated the characteristics of 
heavy metal pollution in the surface paddy soils surrounding the smelter, an integrated assessment of the source-soil-plant system is needed in the future research.

\subsection{Implications for Sustainable Agricuture and Heavy Metal Contamination Control}

With the help of the speciation analysis of $\mathrm{Cu}$ and $\mathrm{Cd}$, we can comprehensively understand the pollution status and risk level of the paddy soils around Guixi smelter. This can help us identify potential major risks and contamination elements in the soil and take effective prevention and control measures accordingly. In addition, the main controlling factors affecting the bioavailability of heavy metals can be found through analyzing the relationship between soil properties and the speciation of heavy metals in the smelterimpacted soil, for example, soil TK was significantly negatively correlated with $\mathrm{CaCl}_{2}-\mathrm{Cu}$, acid-soluble $\mathrm{Cu}$, and oxidizable $\mathrm{Cu}$, which suggests an important technical path to control $\mathrm{Cu}$ pollution in the paddy soil; however, the internal mechanism is being further studied to provide scientific and effective recommendations for pollution regulation in sustainable use of agricultural soils.

\section{Conclusions}

The serious combined pollution of $\mathrm{Cu}$ and $\mathrm{Cd}$ was observed in the surface paddy soil around the smelter. There was a high ecological risk related to $\mathrm{Cd}$, and the available $\mathrm{Cd}$ fraction accounted for $>47 \%$ of TCd, while the soil $\mathrm{Cu}$ was dominantly reserved in stable residual species. $\mathrm{CaCl}_{2}$-Cd was effectively predicted using F1-Cd and F2-Cd, with $R^{2}>0.67$. Several soil properties were significantly correlated with soil Cd but played a small role in its variability with a poor linear fit because of external Cd input to the soil, while soil TK largely influenced the soil $\mathrm{Cu}$ species, except $\mathrm{F} 4-\mathrm{Cu}$, and can provide an effective $\mathrm{Cu}$ pollution regulation strategy through soil $\mathrm{K}$ control in smelter-impacted soil.

Supplementary Materials: The following are available online at https://www.mdpi.com/article/ 10.3390/su132313359/s1, Figure S1: Relationship between $\mathrm{CaCl}_{2}-\mathrm{Cu}$ and the other $\mathrm{Cu}$ species in surface paddy soil in the study area, Figure S2: Relationship between $\mathrm{CaCl}_{2}-\mathrm{Cd}$ and the other $\mathrm{Cd}$ species in surface paddy soil in the study area, Figure S3: Relationship between $\mathrm{Cu}$ and $\mathrm{Cd}$ species with soil mechanical composition, Table S1: Classification standard of pollution degree based on the geoaccumulation index, Table S2: Classification standard of pollution degree based on the potential ecological risk index, Table S3: Statistical characteristics of soil pH in the surface paddy soil around the smelter, Table S4: Correlation analyses (Pearson's tests) between the different chemical speciation of $\mathrm{Cu}$ and $\mathrm{Cd}$ in soil in the study area, Table S5: Correlation analyses between the different chemical speciation of $\mathrm{Cu}, \mathrm{Cd}$ and soil physiochemical properties in soil in the study area.

Author Contributions: Conceptualization, X.W. and Y.L.; methodology, N.G.; software, X.L.; validation, X.W., L.L. and N.G.; formal analysis, X.S.; investigation, X.W. and Z.X.; resources, X.S.; data curation, L.L.; writing—original draft preparation, X.W.; writing—review and editing, Y.L.; visualization, L.L.; supervision, N.G.; project administration, Y.L.; funding acquisition, X.W. and Y.L. All authors have read and agreed to the published version of the manuscript.

Funding: This work was supported by the National Natural Science Foundation of China (No.41867002, 41867065); the Key Research and Development Project of Jiangxi Province (No. 20192BBF60054); the Project of Outstanding Young Scientist of Science and Technology Innovation of Jiangxi Province (No. 20192BCB23026); the Doctoral Fund Project of Jiangxi Academy of Sciences (No.2017-YYB-01); and the Inclusive Project of Jiangxi Academy of Sciences (No.2017-XTPH1-01).

Institutional Review Board Statement: Not applicable.

Informed Consent Statement: Not applicable.

Data Availability Statement: Data presented in this study are available in supplementary material.

Conflicts of Interest: The authors declare no conflict of interest. 


\begin{abstract}
Abbreviations
$\mathrm{SOC}$, soil organic carbon; $\mathrm{CV}$, coefficient of variation; $\mathrm{CaCl} 2-\mathrm{Cu}, \mathrm{CaCl}$-extractable $\mathrm{Cu}$; $\mathrm{CaCl} 2-\mathrm{Cd}, \mathrm{CaCl} 2$-extractable $\mathrm{Cd}$; $\mathrm{TCd}$, total $\mathrm{Cd}$; $\mathrm{TCu}$, total $\mathrm{Cu}$; $\mathrm{BCR}$, Community Bureau of Reference; F1, acid-soluble fraction; F2, reducible fraction; F3, oxidizable fraction; F4, residual fraction; HA, humic acid; FA, fulvic acid; Res-C, residual organic carbon; $\mathrm{AP}$, available phosphorus; $\mathrm{AK}$, available potassium; $\mathrm{AN}$, available nitrogen; $\mathrm{CEC}$, cation exchange capacity; TP, total phosphorus; TK, total potassium; Clay, soil clay content; Silt, soil silt content; Sand, soil sand content.
\end{abstract}

\title{
References
}

1. Koda, E.; Miszkowska, A.; Sieczka, A.; Osiński, P. Heavy metals contamination within restored landfill site in Poland. Environ. Geotech. 2020, 7, 512-521. [CrossRef]

2. Gworek, B.; Dmuchowski, W.; Koda, E.; Marecka, M.; Baczewska, A.H.; Bragoszewska, P.; Sieczka, A.; Osiński, P. Impact of the Municipal Solid Waste Łubna Landfill on Environmental Pollution by Heavy Metals. Water 2016, 8, 470. [CrossRef]

3. Wu, H.; Yang, F.; Li, H.; Li, Q.; Zhang, F.; Ba, Y.; Cui, L.; Sun, L.; Lv, T.; Wang, N.; et al. Heavy metal pollution and health risk assessment of agricultural soil near a smelter in an industrial city in China. Int. J. Environ. Health Res. 2020, 30, 174-186. [CrossRef]

4. Huang, G.; Ding, C.; Zhou, Z.; Zhang, T.; Wang, X. A tillering application of zinc fertilizer based on basal stabilization reduces Cd accumulation in rice (Oryza sativa L.). Ecotox. Environ. Safe. 2019, 167, 338-344. [CrossRef]

5. Zhang, X.; Zhong, T.; Liu, L.; Ouyang, X. Impact of soil heavy metal pollution on food safety in China. PLoS ONE 2015, 10, e0135182. [CrossRef] [PubMed]

6. Liu, H.; Zhou, J.; Li, M.; Hu, Y.; Liu, X.; Zhou, J. Study of the bioavailability of heavy metals from atmospheric deposition on the soil-pakchoi (Brassica chinensis L.) system. J. Hazard. Mater. 2019, 362, 9-16. [CrossRef]

7. Hu, N.J.; Li, Z.Q.; Huang, P.; Tao, C. Chemical forms of heavy metals in sewage-irrigated paddy soil in Guixi city. J. Agro-Environ. Sci. 2004, 23, 683-686. (In Chinese)

8. Zhou, J. Present situation and prospects of technologies for remediation of heavy-metal-contaminated soil around Jiangxi Guixi Smelter. World Environ. 2016, 161, 48-53.

9. Cui, H.; Fan, Y.; Yang, J.; Xu, L.; Zhou, J.; Zhu, Z. In situ phytoextraction of copper and cadmium and its biological impacts in acidic soil. Chemosphere 2016, 161, 233-241. [CrossRef]

10. Xu, L.; Cui, H.; Zheng, X.; Zhu, Z.; Liang, J.; Zhou, J. Immobilization of copper and cadmium by hydroxyapatite combined with phytoextraction and changes in microbial community structure in a smelter-impacted soil. Rsc. Adv. 2016, 6, 103955-103964. [CrossRef]

11. Soliman, N.F.; El Zokm, G.M.; Okbah, M.A. Risk assessment and chemical fractionation of selected elements in surface sediments from Lake Qarun, Egypt using modified BCR technique. Chemosphere 2018, 191, 262-271. [CrossRef] [PubMed]

12. Gabarrón, M.; Zornoza, R.; Martínez-Martínez, S.; Muñoz, V.A.; Faz, Á.; Acosta, J.A. Effect of land use and soil properties in the feasibility of two sequential extraction procedures for metals fractionation. Chemosphere 2019, 218, 266-272. [CrossRef] [PubMed]

13. Tong, L.; He, J.; Wang, F.; Wang, Y.; Wang, L.; Tsang, D.; Hu, Q.; Hu, B.; Tang, Y. Evaluation of the BCR sequential extraction scheme for trace metal fractionation of alkaline municipal solid waste incineration fly ash. Chemosphere 2020, $249,126115$. [CrossRef] [PubMed]

14. Ennaji, W.; Barakat, A.; Baghdadi, M.E.; Rais, J. Heavy metal contamination in agricultural soil and ecological risk assessment in the northeast area of Tadla plain, Morocco. J. Sediment. Environ. 2020, 5, 307-320. [CrossRef]

15. Guo, F.; Ding, C.; Zhou, Z.; Huang, G.; Wang, X. Stability of immobilization remediation of several amendments on cadmium contaminated soils as affected by simulated soil acidification. Ecotoxicol. Environ. Saf. 2018, 161, 164-172. [CrossRef] [PubMed]

16. Guo, X.J.; Xie, X.; Liu, Y.D.; Wang, C.; Yang, M.; Huang, Y. Effects of digestate DOM on chemical behavior of soil heavy metals in an abandoned copper mining areas. J. Hazard. Mater. 2020, 393, 122436. [CrossRef] [PubMed]

17. Zhang, L.X.; Zhu, G.; Ge, X.; Xu, G.; Guan, Y. Novel insights into heavy metal pollution of farmland based on reactive heavy metals (RHMs): Pollution characteristics, predictive models, and quantitative source apportionment. J. Hazard. Mater. 2018, 360, 32-42. [CrossRef] [PubMed]

18. Huang, B.; Yuan, Z.; Li, D.; Zheng, M.; Nie, X.; Liao, Y. Effects of soil particle size on the adsorption, distribution, and migration behaviors of heavy metal (loid) s in soil: A review. Environ. Sci. Proc. Imp. 2020, 22, 1596-1615. [CrossRef]

19. Qaswar, M.; Liu, Y.; Huang, J.; Liu, K.; Mudasir, M.; Lv, Z.; Hou, H.; Lan, X.; Ji, J.; Ahmed, W.; et al. Soil nutrients and heavy metal availability under long-term combined application of swine manure and synthetic fertilizers in acidic paddy soil. J. Soils Sediments 2020, 20, 2093-2106. [CrossRef]

20. Wang, X.; Min, F.; Yu, D.; Xin, Z.; Li, L.; Li, X.; Sun, X.; Pan, J. Mean residence times of active and slow soil organic carbon pools in croplands across China. CATENA 2021, 202, 105271. [CrossRef]

21. Zhou, H.; Zhou, X.; Zeng, M.; Liao, B.; Liu, L.; Yang, W.; Wu, Y.; Qiu, Q.; Wang, Y. Effects of combined amendments on heavy metal accumulation in rice (Oryza sativa L.) planted on contaminated paddy soil. Ecotoxicol. Environ. Saf. 2014, 101, $226-232$. [CrossRef] [PubMed] 
22. Lu, R.K. Analytical Methods for Soil and Agro-Chemistry; China Agricultural Science and Technology Press: Beijing, China, 2000. (In Chinese)

23. Yu, T.R.; Wang, Z.Q. Soil Analytical Chemistry; Science Press: Beijing, China, 1988. (In Chinese)

24. Ma, Q.; Zhao, W.; Guan, D.X.; Teng, H.H.; Ji, J.; Ma, L.Q. Comparing $\mathrm{CaCl}_{2}$, EDTA and DGT methods to predict Cd and Ni accumulation in rice grains from contaminated soils. Environ. Pollut. 2020, 260, 114042. [CrossRef] [PubMed]

25. Muller, G. Indice of geoaccumulation in sediments of the Rhime River. GeoJournal 1969, 2, 109-118.

26. Förstner, U.; Ahlf, W.; Calmano, W. Sediment quality objectives and criteria development in Germany. Water Sci. Technol. 1993, 28, 307-314. [CrossRef]

27. Hakanson, L. An ecological risk indice for aquatic pollution control. A sedimentological approach. Water Res. 1980, 14, 975-1001. [CrossRef]

28. Xu, Z.Q.; Ni, S.J.; Tuo, X.G.; Zhang, C.J. Calculation of heavy metals' toxicity coefficient in the evaluation of potential ecological risk indice. Environ. Sci. Technol. 2008, 31, 112-115. (In Chinese)

29. Zhang, Z.; Wang, J.J.; Ali, A.; DeLaune, R.D. Physico-chemical forms of copper in water and sediments of Lake Pontchartrain basin, USA. Chemosphere 2018, 195, 448-454. [CrossRef]

30. Leech, N.L.; Barret, K.K.C.; Morgan, G. SPSS for Intermediate Statistics; Lawrence Erlbaum Associates: New York, NY, USA, 2008; p. 270.

31. Xu, S.; Gong, X.; Liu, C.; Chen, C.; Zeng, H.; Wang, J.; Li, Z.; Zheng, L. Ecological risk assessment and pollution analysis on the heavy mentals contaminated soil around Guixi smeltery. J. Nanchang Univ. 2015, 39, 96-102. (In Chinese)

32. Giannakis, I.; Emmanouil, C.; Mitrakas, M.; Manakou, V.; Kungolos, A. Chemical and ecotoxicological assessment of sludge-based biosolids used for corn field fertilization. Environ. Sci. Pollut. Res. 2021, 28, 3797-3809. [CrossRef]

33. Huang, Y.; Chen, Q.; Deng, M.; Japenga, J.; Li, T.; Yang, X.; He, Z. Heavy metal pollution and health risk assessment of agricultural soils in a typical peri-urban area in southeast China. J. Environ. Manag. 2018, 207, 159-168. [CrossRef] 